\title{
Granzymes and perforin in solid organ transplant rejection
}

JC Choy ${ }^{\star 1}$

Rejection of solid organ allografts by the recipient immune system is mediated, to a major extent, by T cell effector mechanisms. Granzymes and perforin are protein regulators of cytotoxic T lymphocyte-mediated target cell death. In this review, I discuss clinical data implicating granzymes and perforin in acute and chronic solid organ transplant rejection, as well as data from cell and animal experiments that support a main role for these effector molecules in allograft rejection.

Cell Death and Differentiation (2010) 17, 567-576; doi:10.1038/cdd.2009.161; published online 30 October 2009

\section{Overview of Solid Organ Transplantation}

Solid organ transplantation is the most effective treatment for end-stage organ failure, but the effectiveness of this procedure continues to be hindered by the rejection of transplanted organs by the recipient immune system. Although immunosuppressive drugs are provided to patients to manage rejection, there remains much room for improvement because the overall half-lives of kidney and heart transplants (two of the main solid organ transplants performed) are only 12 and 10 years, respectively. ${ }^{1,2}$ In addition, the most widely used immunosuppressive drugs, calcineurin inhibitors (which include cyclosporine and tacrolimus) and rapamycin, are non-specific and are associated with detrimental side effects that include kidney damage, increased risk of cardiovascular disease, increased susceptibility to certain malignancies, and increased rate of certain infections. ${ }^{3}$ Advancements in organ transplant management have focused on the induction of tolerance, a process in which immune modulation of the recipient can specifically prevent detection and/or targeting of the foreign organ. Progress is being made on the induction of tolerance in humans, although its widespread clinical use remains to be determined. ${ }^{4-6}$

To optimize the success of organ transplantation, a better understanding of the mechanisms by which the immune system targets allografts is needed. In general, rejection of allografts involves antibody and $\mathrm{T}$ cell responses. In this review, I discuss specifically the role of granzymes and perforin, which are the main effector molecules of cytotoxic T lymphocytes (CTLs), in causing acute and chronic solid organ transplant rejection.

\section{Granzyme/Perforin Effector Pathways}

Cytotoxic T lymphocytes (which include CD8 and some CD4 $T$ cells) and NK cells are involved in the elimination of infected and foreign cells by the immune system. CD8 T cells are the best understood CTL population. Resting CD8 T cells differentiate into CTLs after an encounter with foreign peptideMHC class I in the context of other activating signals. ${ }^{7}$ These CTLs then migrate to sites of immune activation and induce the death of target cells. In addition to T cells, recognition of activating receptors and a lack of inhibitory signals triggers the NK cell-mediated killing of infected or foreign cells. ${ }^{8}$

One of the most potent death-inducing mechanisms used by CTLs and NK cells is granule exocytosis. Cytotoxic granules contain the pore-forming protein, perforin, and serine proteases named granzymes. The human genome encodes five granzymes: granzyme (Gr)A and $\mathrm{GrB}$, and the orphan granzymes $\mathrm{GrH}, \mathrm{GrK}$, and $\mathrm{GrM}$. The mouse genome encodes for granzymes $\mathrm{GrA}$ and $\mathrm{GrB}$, and the orphan granzymes $\mathrm{GrC}$, $\mathrm{GrD}, \mathrm{GrE}, \mathrm{GrF}, \mathrm{GrG}, \mathrm{GrK}, \mathrm{GrM}$, and $\mathrm{GrN}$, but not for $\mathrm{GrH} .{ }^{9}$ On lymphocyte recognition of target cells, granule contents are rapidly released into the lymphocyte-target cell synapse. Perforin facilitates the entry of granzymes into the target cell cytoplasm where these serine proteases induce cell death through a number of pathways. ${ }^{10}$

$\mathrm{GrB}$ is the most extensively studied granzyme that induces cell death through the activation of caspase-dependent and independent pathways (Figure 1a). Specifically, human GrB can directly cleave the proapoptotic protein Bid, which generates an active form of Bid that translocates to the mitochondria and induces permeability of this organelle. ${ }^{11,12}$ This Bcl-2regulated pathway has rapid kinetics and causes the release of cytochrome $c$, which leads to caspase activation, as well as the release of SMAC/Diablo, which augments caspase activation by inactivating the endogenous inhibitors of caspases. ${ }^{13,14} \mathrm{GrB}$ also acts on the mitochondria by inducing caspase-independent cell death through the generation of reactive oxygen species (ROS).${ }^{15}$ In addition to acting through a mitochondrial pathway, GrB induces apoptosis by directly \footnotetext{
Canada V5A 1 S6.

Tel: + 1778782 8701; Fax: +1 778782 5583; E-mail: jonathan.choy@sfu.ca

Keywords: transplantation; granzyme; perforin

Abbreviations: AV, allograft vasculopathy; CTL, cytotoxic T lymphocyte

Received 20.8.09; accepted 24.9.09; Edited by D Granville; published online 30.10 .09
}

${ }^{1}$ Department of Molecular Biology and Biochemistry, Simon Fraser University, Burnaby, British Columbia, Canada

${ }^{*}$ Corresponding author: JC Choy, Department of Molecular Biology and Biochemistry, Simon Fraser University, 8888 University Drive, Burnaby, British Columbia, 


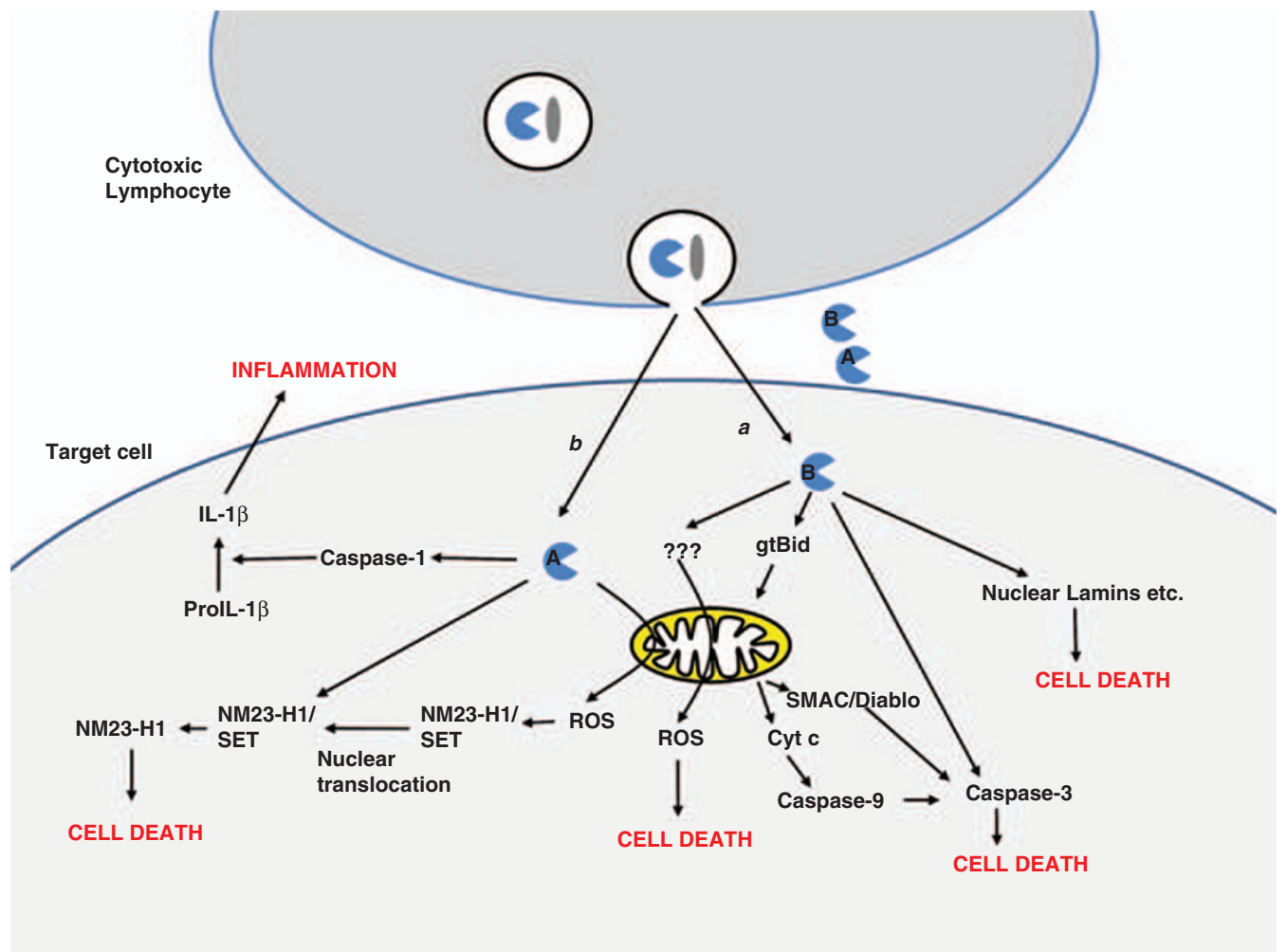

Figure 1 Granzyme A and B (GrA and GrB)-mediated cell death pathways. On recognition of foreign cells, activated CTLs release granzymes and perforin into the lymphocyte-target cell synapse. Perforin facilitates the entry of granzymes into the target cell cytoplasm. (a) Once inside the target cell, GrB induces cell death through a number of mechanisms. GrB-mediated cleavage of Bid results in the generation of an active form of Bid, which causes mitochondrial permeability. Downstream release of cytochrome $\mathrm{c}$ initiates caspase activation. SMAC/Diablo is also released by mitochondrial permeabilization and this molecule augments caspase activity by preventing caspase inhibition by endogenous inhibitors. GrB also directly cleaves and activates caspase- 3 . In the absence of caspase activation, GrB can induce cell death through the induction of ROS from mitochondria as well as through the direct cleavage of structural proteins, such as nuclear lamins. (b) GrA acts directly on mitochondria to induce the production of ROS. Generation of ROS induces the translocation of the SET complex, which contains the SET protein that binds to and inhibits the endonuclease NM23-H1 in the nucleus. GrA cleaves and inactivates SET in the nucleus, which allows NM23-H1 to cleave DNA into large fragments. In addition to these death-inducing properties of GrA, this serine protease induces inflammation through the production of IL-1 $\beta$ through a caspase-1-dependent mechanism

cleaving and activating caspase- $3 .{ }^{16}$ In situations in which caspase activity is blocked, GrB can directly cleave and inactivate proteins involved in cellular structure and function, such as nuclear lamins, and in this way contribute to the dismantling of target cells through a caspase-independent mechanism. ${ }^{17}$ In all, GrB induces cell death through several pathways that may maximize its effectiveness in clearing pathogens that evolve strategies to evade specific pathways.

GrA is also expressed by CTLs and NK cells. Cell death induced by this protease is morphologically distinct from apoptosis and is characterized by cell rounding and cleavage of DNA into relatively large fragments. ${ }^{18}$ This trypsin-like protease induces caspase-independent death in vitro by triggering the generation of ROS and releasing the endonuclease, NM23-H1, from inhibition (Figure 1b). ${ }^{19-21}$ These processes lead to the cleavage of DNA into large fragments in the target cell nucleus. Interestingly, GrA induces the generation of ROS through direct cleavage of the mitochondrial matrix complex I protein, NDUSF $3{ }^{22}$ Other granzymes can also induce cell death in vitro and the specific pathways are just beginning to be defined. ${ }^{23-25}$

The physiological roles of perforin and granzymes have been studied using gene knockout mice. Perforin-deficient mice have increased susceptibility to certain viruses and develop autoimmunity secondary to viral infection. ${ }^{26-30}$ In comparison, GrB and GrA knockout mice are susceptible to a limited number of pathogens, although $\mathrm{GrA} / \mathrm{GrB}$ double knockout mice may closely resemble perforin knockout mice in their defective clearance of viral infections. ${ }^{31-33}$ The immunological defects observed in GrB and perforin knockout mice are likely a result of impaired induction of target cell death because perforindeficient $T$ cells are unable to kill most cell types in ex vivo killing assays and GrB-deficient $T$ cells have a significant delay in their ability to induce target cell death in similar assays. ${ }^{34}$ The mechanisms by which GrA contributes to immunity are still being investigated, but may involve the induction of target cell death and/or of inflammatory cytokine production. Although GrA induces cell death in vitro, a recent report questioned the ability of murine GrA to induce target cell death in vivo and showed instead that it induces inflammation by stimulating the production of IL- $1 \beta$ from monocytes. ${ }^{35}$

\section{CD8 T Cells and NK Cells in Acute Allograft Rejection}

CD8 and CD4 T cells are present in acutely rejecting allografts along with a small number of NK cells. ${ }^{36,37}$ Interestingly, 


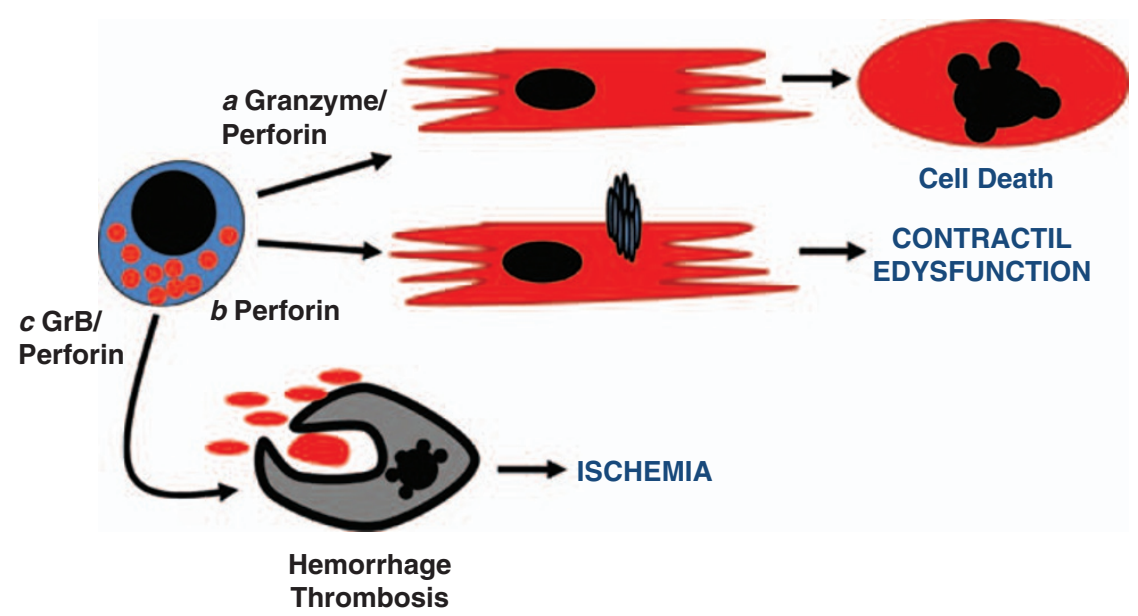

Figure 2 Role of granzymes and perforin in acute rejection. (a) Granzymes/perforin act together to directly induce cell death of allograft parenchymal cells, thereby leading to organ failure. (b) In heart allografts, the formation of plasma membrane pores by perforin alone may cause cardiac myocyte contractile dysfunction through the dysregulation of cytoplasmic ion concentrations. (c) Granzyme B (GrB) and perforin act together to induce endothelial cell death within solid organ allografts. The destruction of the graft microvasculature in this manner leads to hemorrhage and thrombosis, thereby contributing to acute rejection by causing ischemic organ failure

memory CD8 T cells may be one of the earliest leukocytes to enter allografts and trigger the rejection process. ${ }^{38}$ In animal models of transplantation using complete MHC-mismatched strains of mice in the absence of immunosuppression, antibody-mediated depletion of CD8 T cells does not alter the kinetics of acute cardiac allograft rejection, but does change the rejection process from one that involves graft infiltration by mononuclear cells to one characterized by excessive infiltration by neutrophils and eosinophils. ${ }^{39}$ As acute rejection is most often associated with mononuclear cell infiltration in clinical settings, these data support the involvement of CD8 $T$ cells in acute organ transplant rejection. In addition, CD8 $T$ cell deficiency prevents the acute rejection of heart allografts in a minor histocompatibility antigenmismatched mouse model. ${ }^{40}$ In addition to T cells, NK cells may also contribute to graft rejection because of their ability to respond to 'missing-self', a process by which the absence of inhibitory signals derived from binding to self peptide-MHC molecules triggers NK cell activation. ${ }^{41-43}$ The above studies establish a role for CTLs and NK cells in causing acute allograft rejection.

\section{Granzymes and Perforin in Acute Allograft Rejection}

Histological studies have shown the abundance of GrA, GrB, and perforin in many types of acutely rejecting allografts. ${ }^{44-49}$ In addition, increased expression of granzymes and perforin is predictive of the development of acute rejection episodes. ${ }^{45,50}$ Further evidence for a role of $\mathrm{GrB}$ in acute transplant rejection comes from the observation that there are higher levels of the endogenous GrB inhibitor, PI-9, within the tubular epithelial cells of kidney allografts with grade IA rejection than in those with more severe acute rejection as defined by grade IB or greater. ${ }^{51}$

Granzyme/perforin pathways are the main mechanisms by which CTLs induce cell death in allografts, as exemplified by cell culture studies using cardiac myocytes, renal tubular epithelial cells, and vascular endothelial cells. Perforin alone induces cardiac myocyte shortening and destruction in vitro, and GrA acts in concert with perforin to accelerate myocyte destruction (Figure 2a). ${ }^{52}$ Interestingly, the pore-forming properties of perforin alone may also contribute to myocyte contractile dysfunction by causing extracellular calcium influx (Figure 2b). Consistent with these in vitro findings, GrA expression is correlated with decreased diastolic function in heart transplant patients. ${ }^{53}$ With regard to renal allografts, Miltenburg et al. $^{54}$ isolated and cultured graft-infiltrating lymphocytes from kidney biopsy material and showed that they were cytolytic toward donor tubular epithelial cells from the same biopsy material but not toward third-party tubular epithelial cells. The determination that cytolytic activity was inhibited by blocking MHC class I suggested the involvement of CD8 T cells. Subsequent studies determined that these graft-infiltrating CTLs induce allogeneic tubular epithelial cell death through a perforin-dependent pathway, as cell death was prevented with concanamycin A but not by inhibition of the Fas pathway. ${ }^{55}$ Finally, in the mouse, GrC is involved in the delayed $T$ cell-mediated killing of allogeneic targets in the absence of active $\mathrm{GrA}$ and $\mathrm{GrB},{ }^{56}$ and this orphan granzyme is partly involved in the T cell-mediated cell death of tubular epithelial cells in an autoimmune model. ${ }^{57}$ Although the human genome does not encode $\mathrm{GrC}$, it will be interesting to determine the role of the related granzyme in humans, $\mathrm{GrH}$, in allogeneic $\mathrm{T}$ cell responses.

Vascular endothelial cells activate allogeneic $T$ cell responses and are also an important target of CTLs in all solid organ allografts. ${ }^{58}$ Endothelial cell-reactive CTLs can be cultured from endomyocardial biopsies, and immunemediated microvascular damage leads to ischemic organ failure by causing hemorrhage and thrombosis. ${ }^{59} \mathrm{GrB}$ acts in concert with perforin to induce rapid cell death of human endothelial cells in vitro, and GrB alone is capable of inducing endothelial cell death at later time points by proteolyzing extracellular proteins required for adhesion-mediated cell survival. ${ }^{60,61}$ Zheng et al. ${ }^{62}$ and Kreisel et al. ${ }^{63}$ investigated the mechanisms by which CD8 T cells kill human and mouse vascular endothelial cells, respectively. In both instances, CD8 T cells induced cell death of allogeneic endothelial cells 
predominantly through a GrB/perforin pathway and there was minimal contribution of the FasL pathway. This may be due to the expression of an endogenous inhibitor of the Fas pathway, c-FLIP, in endothelial cells. ${ }^{64,65}$ Using a humanized mouse model of $\mathrm{T}$ cell-mediated endothelial cell injury in which human endothelial cell engraftment in SCID/beige mice is followed by the adoptive transfer of allogeneic human T cells, Zheng et al. ${ }^{66}$ also determined that human $T$ cell induction of allogeneic endothelial cell death is inhibited by $\mathrm{Bcl}-2$ in vivo. Finally, the susceptibility of endothelial cells to GrB/perforinmediated injury is likely to be tightly regulated by cytokines because IFN $\gamma$ signaling in graft cells reduces GrB/perforininduced microvascular damage in a mouse model of kidney transplantation. $^{67}$

Animal models have been used to determine the role of granzymes and perforin in acute organ transplant rejection (Table 1). Although it is clear that CTLs predominantly use granzyme/perforin pathways to induce allogeneic target cell death, experiments using complete $\mathrm{MHC}$-mismatched animal models of organ transplant rejection in the absence of immunosuppression have failed to identify a requirement for perforin/granzyme pathways in allograft rejection in this setting. ${ }^{68,69}$ Specifically, in these models there is no difference in cardiac allograft survival (as determined by palpation) or kidney allograft rejection (as determined by histology) in perforin or granzyme knockout recipients compared with wild-type counterparts. This may be explained by a predominance of antibody-mediated rejection in these models. Indeed, acute rejection of heterotopic heart transplants that occurs in complete $\mathrm{MHC}$-mismatched recipients in the absence of immunosuppression is due in large part to antibody-mediated graft injury. ${ }^{70,71}$ Clinically, antibodymediated rejection is implicated in 5.6-23\% of rejecting ABO-matched kidney allografts, $30-60 \%$ of ABO-mismatched kidney allografts, and $3-28 \%$ of heart allografts (although there was an incidence as high as $52 \%$ in one report). ${ }^{72,73}$ These data indicate that there is a substantial contribution of $T$ cell-mediated rejection (as reflected by the large proportion of clinical cases in which antibody-mediated rejection is not implicated) that may not be accurately reflected in complete MHC-mismatched mouse models in the absence of immunosuppression. CTL cytotoxic effector pathways are likely to be the main mechanism of rejection in patients undergoing this type of cellular rejection. In fact, immunosuppression with cyclosporine might preferentially inhibit humoral immune responses in some cases, ${ }^{74}$ potentially resulting in an increased contribution of CD8 T cell responses to allograft rejection in the presence of this immunosuppressive drug. This has been observed in a murine aortic allograft model of vascular rejection. ${ }^{75}$ Therefore, in allografts in which antibodymediated rejection is implicated, the immune effector pathways involved probably include both antibody and $\mathrm{T}$ cellmediated graft injury, whereas the effector pathways involved in allografts that are undergoing rejection in the absence of antibody-mediated graft destruction include mainly $\mathrm{T}$ cell pathways such as CTL and cytokine-mediated graft cell death and dysfunction. Individual patient differences in the quality of immune responses and susceptibility to immunosuppressive drugs may underlie the respective contribution of each effector pathway in specific patients. Understanding the

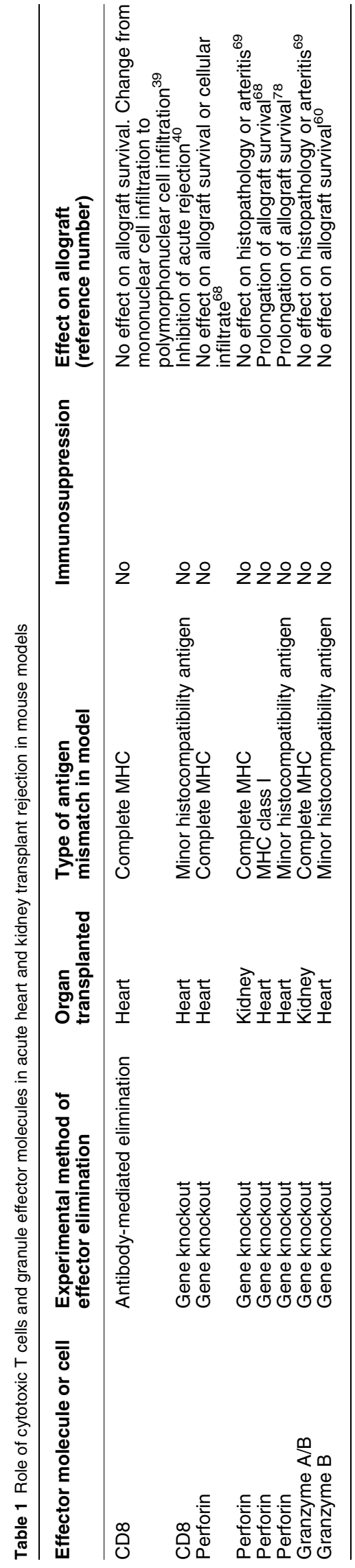


regulation of both effector pathways is required to optimize future therapeutic approaches, such as co-stimulatory blockade and tolerance induction, that are effective in preventing both immunological responses. ${ }^{76}$

Given the contribution of CTL cell effector pathways in allograft rejection as outlined above, it is important to understand the role of specific effector molecules in this process. In a murine heterotopic heart transplant model across minor histocompatibility antigen-mismatched strains, which is a situation in which there is minimal antibodymediated targeting of allografts, acute heart transplant rejection is significantly delayed in perforin-deficient recipients. ${ }^{77,78}$ Perforin is also required for the acute rejection of mouse heterotopic heart allografts performed across MHC class I disparate strains. ${ }^{68}$ Although these experiments show that perforin is required for the cellular rejection of solid organ allografts, there is no difference in the rate of acute cardiac allograft rejection in GrB cluster-deficient recipients (which lack $\mathrm{GrB}$ and have reduced expression of $\mathrm{GrC}, \mathrm{GrF}$, and $\mathrm{GrD}$ ) compared with wild-type counterparts. ${ }^{60}$ This could be due to redundancy in the granzyme pathways and it will be important to determine the rejection of cardiac allografts in $\mathrm{GrA} / \mathrm{GrB}$ double knockout mice in this model.

In addition to inducing cell death directly, GrA may be proinflammatory in allografts through the induction of $\mathrm{IL}-1 \beta$ production. Neutralization of IL-1 with a soluble receptor antagonist slightly prolongs heterotopic heart transplant survival, and blocking IL-1 signaling acts in synergy with cyclosporine to prolong heart transplant survival. ${ }^{79,80}$ The recent identification that murine GrA induces IL-1 $\beta$ production from monocytes suggests that there may be additional noncytotoxic properties of granzymes that may contribute to organ transplant rejection by increasing leukocyte recruitment and activation, as well as vascular cell dysfunction. ${ }^{35}$

\section{Granzymes and Perforin in Chronic Allograft Rejection}

To date, advances in immunosuppressive regimens have decreased graft failure because of acute rejection, but have had limited impact on chronic rejection. ${ }^{1}$ This difference in efficacy could reflect distinctions in the pathological mechanisms driving acute and chronic rejection, although there are clearly similar immunological processes involved. Chronic rejection is defined as late graft loss because of host anti-graft immune responses, ${ }^{81}$ and it is represented mainly by allograft vasculopathy $(\mathrm{AV})$ and parenchymal fibrosis. $A V$ is a vascular condition characterized by immune-mediated arterial intimal thickening and dysfunction. These vascular changes result in vessel occlusion and resultant ischemic graft failure. ${ }^{82}$ Fibrosis of the graft parenchyma is observed as a reflection of chronic rejection in most solid organ allografts and is one of the structural changes that defines chronic allograft nephropathy (CAN) in kidney allografts. The exact mechanisms underlying the development of parenchymal fibrosis remain to be fully defined, but may include early graft damage due to acute rejection episodes, ischemia resulting from $A V$, or production of fibrosis-inducing cytokines by the immune responses. $^{81}$

Chronic rejection involves $\mathrm{T}$ cell responses. Analysis of clinical specimens of $\mathrm{AV}$ has shown that both CD8 and
CD4 $\mathrm{T}$ cells accumulate in allograft arteries. ${ }^{83}$ There is also a small number of NK cells that infiltrates the arteries of heart allografts. ${ }^{84}$ Intimal thickening of complete MHCmismatched aortic allografts does not develop in Rag - and CD4 T cell-deficient recipient mice. ${ }^{85}$ Although CD8 T cells do not seem to be required for the development of intimal thickening in mouse models of AV that use complete MHCmismatched strains of mice in the absence of immunosuppression, ${ }^{85} \mathrm{CD} 8 \mathrm{~T}$ cells are required for the development of $\mathrm{AV}$ in a complete $\mathrm{MHC}$-mismatched model that includes the treatment of mice with a clinically relevant cyclosporine-based immunosuppressive regimen. ${ }^{75}$ The mechanisms by which $\mathrm{T}$ cells cause AV involve both the direct cytokine-mediated dysfunction of graft cells as well as CTL-mediated vascular cell damage. ${ }^{86,87}$ The role of CTL responses in AV and CAN is discussed below, and specific studies are summarized in Table 2.

Using mechanical injury models of arterial intimal thickening, Ross et al. initially showed that endothelial injury leads to an aberrant reparative response in arteries characterized by rapid smooth muscle cell migration from the media into the intima, whereupon these cells proliferate rapidly to form occlusive lesions. ${ }^{88}$ The signals mediating this type of intimal thickening involve the production of growth factors by vascular smooth muscle cells, infiltrating leukocytes, and platelets. As $\mathrm{AV}$ is characterized by similar rapid intimal thickening and lesions containing large numbers of smooth muscle cells and leukocytes, immune-mediated endothelial injury could be an initiating event in the development of this vascular condition. ${ }^{89}$ In support of this notion, there is extensive endothelial cell apoptosis in human specimens of $\mathrm{AV} .^{90}$ Interestingly, the number of apoptotic luminal endothelial cells is highest in arteries with mild AV (which perhaps resembles an early stage of $\mathrm{AV}$ ) and lower at later stages. Extensive endothelial cell death is also observed in allograft arteries early after heterotopic heart transplantation in a rat model. ${ }^{91}$ Separate studies also showed that infiltrating $T$ cells express perforin in allograft arteries. ${ }^{92}$ Many of the observed perforin-expressing $T$ cells localized to endothelial cells that displayed morphological characteristics of damage, and perforin-containing granules were seen to be polarized toward the endothelial surface. ${ }^{93}$ Finally, GrB is also abundant in human specimens of $\mathrm{AV}$ and is spatially associated with apoptotic cells. Its increased abundance in allograft arteries is associated with increased intimal thickening. ${ }^{94}$

The above data suggest that CTLs may initiate the development of AV by inducing endothelial cell death through a GrB/perforin pathway. To study this experimentally, we examined the effects of perforin or GrB deficiency on the development of $\mathrm{AV}$ in a mouse heterotopic heart transplant model in which minor histocompatibility antigen-mismatched strains of mice were used to prevent early antibody-mediated graft destruction. There was a significant reduction in AV in hearts transplanted into perforin knockout recipients compared with wild-type counterparts, and this was related to a significant reduction in early endothelial cell apoptosis in coronary arteries of hearts transplanted into perforin knockout recipients compared with wild-type counterparts. ${ }^{78}$ Similarly, in hearts transplanted into GrB cluster knockout recipients, there was a significant reduction in the extent of intimal 
Table 2 Role of cytotoxic T cells and granule effector molecules on AV in mouse models

\begin{tabular}{|c|c|c|c|c|c|}
\hline $\begin{array}{l}\text { Effector cell } \\
\text { or molecule }\end{array}$ & $\begin{array}{l}\text { Experimental method } \\
\text { of effector elimination }\end{array}$ & $\begin{array}{l}\text { Transplanted } \\
\text { tissue/organ }\end{array}$ & $\begin{array}{l}\text { Type of antigen } \\
\text { mismatch in model }\end{array}$ & Immunosuppression & $\begin{array}{l}\text { Effect on AV } \\
\text { (reference number) }\end{array}$ \\
\hline CD8 & Gene knockout & Aortic allograft & Complete MHC & No & None $^{85}$ \\
\hline CD8 & $\begin{array}{l}\text { Antibody-mediated } \\
\text { elimination }\end{array}$ & Aortic allograft & Complete MHC & Yes-cyclosporine & $\begin{array}{l}\text { Reduced intimal } \\
\text { thickening }\end{array}$ \\
\hline Perforin & Gene knockout & Kidney & Complete MHC & No & $\begin{array}{l}\text { No effect on intimal } \\
\text { thickening }\end{array}$ \\
\hline Perforin & Gene knockout & $\begin{array}{l}\text { Heterotopic } \\
\text { heart }\end{array}$ & $\begin{array}{l}\text { Minor histocompatibility } \\
\text { antigen }\end{array}$ & No & $\begin{array}{l}\text { Reduced intimal } \\
\text { thickening }\end{array}$ \\
\hline Granzyme A/B & Gene knockout & Kidney & Complete MHC & No & $\begin{array}{l}\text { No effect on intimal } \\
\text { thickening }\end{array}$ \\
\hline Granzyme B & Gene knockout & $\begin{array}{l}\text { Heterotopic } \\
\text { heart }\end{array}$ & $\begin{array}{l}\text { Minor histocompatibility } \\
\text { antigen }\end{array}$ & No & $\begin{array}{l}\text { Reduced intimal } \\
\text { thickening }\end{array}$ \\
\hline
\end{tabular}

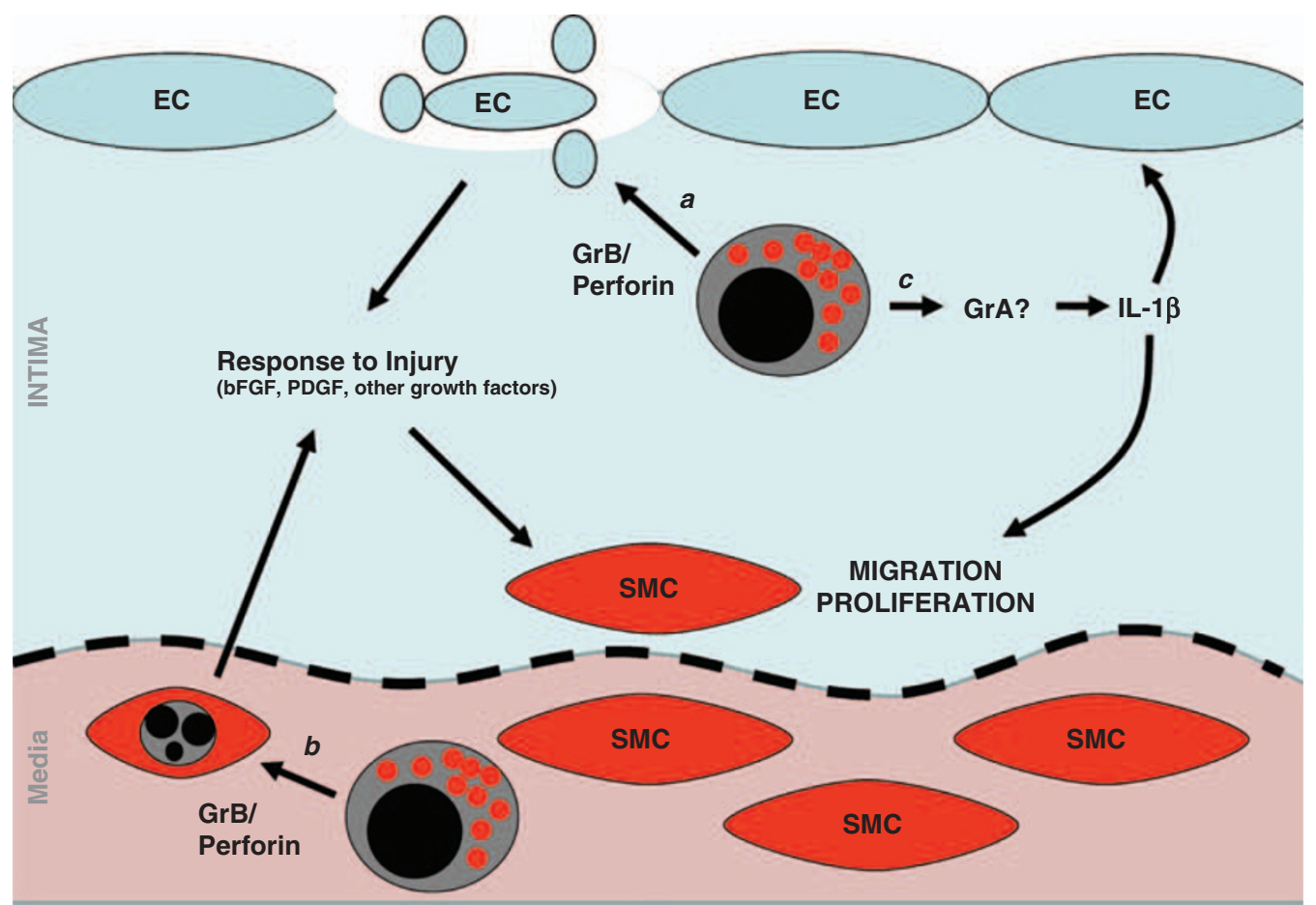

Figure 3 Role of granzymes and perforin in AV. (a) Cytotoxic T lymphocytes infiltrating allograft arteries induce cell death of luminal endothelium through a GrB/perforin pathway. This endothelial destruction induces a response to injury in the artery that involves the production of growth factors, which induce the migration and proliferation of medial smooth muscle cells in the arterial intima. (b) In addition to endothelial damage, induction of smooth muscle cell death by CD8 T cells may also be mediated by GrB and perforin. Smooth muscle cell death may also initiate a response to injury characterized by intimal migration and proliferation of this cell type. (c) GrA may also potentiate inflammation within allograft arteries by inducing the production of IL-1 $\beta$. This could augment intimal hyperplasia within allograft arteries by stimulating smooth muscle cell proliferation and/or or inhibiting cell death. II-1 $\beta$ may also activate endothelial cells to produce immune-stimulating cytokines, chemokines, and cell surface adhesion molecules

thickening in allograft coronary arteries compared with hearts in wild-type recipients. ${ }^{60}$ However, there was slightly more AV in allograft arteries in GrB cluster knockout compared with perforin knockout mice. Taken together, the above studies indicate that perforin and GrB contribute to the pathogenesis of $\mathrm{AV}$ by causing early endothelial cell death (Figure $3 \mathrm{a}$ ). In addition, perforin-dependent but GrB-independent pathways are involved. The identity of these pathways has not been determined, but they could involve GrA. Finally, as neither perforin nor GrA/B deficiency affects intimal thickening in a mouse kidney allograft model using complete MHC-mismatched strains of mice in the absence of immunosuppression, ${ }^{69}$ the granzyme/perforin pathway is likely to predominate in the initiation of $\mathrm{AV}$ in allograft arteries that are targeted mainly by $\mathrm{T}$ cell effector responses, whereas antibodymediated targeting of allograft arteries also contributes to $\mathrm{AV}$ in grafts in which antibody responses are present.

In addition to the induction of endothelial cell death, immune-mediated smooth muscle cell death may also contribute to the development of AV (Figure 3b). Using mechanical injury models, Reidy et al. ${ }^{95}$ showed that smooth muscle cell death can also initiate a response to injury within the arteries, thereby leading to intimal hyperplasia. Recent studies using transgenic mice that express diphtheria toxin receptor on vascular smooth muscle cells failed to observe the initiation of widespread intimal thickening in response to high 
levels of smooth muscle cell death under baseline conditions induced by the administration of diphtheria toxin, perhaps suggesting that the type of smooth muscle damage may be important in determining the specific effects on vascular pathology. ${ }^{96}$ In the setting of transplantation, CD8 T cellmediated smooth muscle cell death has been suggested to contribute to the development of $\mathrm{AV}$ in a clinically relevant mouse model of $\mathrm{AV} .{ }^{97}$ Consistent with these experimental data, GrB localizes to apoptotic smooth muscle cells in clinical specimens of $A V$ and this cytotoxic protease is able to induce smooth muscle cell death in a perforin-independent manner by cleaving extracellular matrix proteins in vitro. ${ }^{94,98}$

Although the above data establish a role for granzymes and perforin in the pathogenesis of $\mathrm{AV}$ and chronic heart allograft failure, the potential involvement of these effector molecules in the development of chronic kidney allograft rejection is less clear. Mouse models have determined that chronic rejection is reduced in renal allografts that lack MHC expression. ${ }^{99}$ CD8 T cells are observed in biopsies from chronically rejecting kidneys and this $T$ cell subset is associated with fibrotic changes in renal allografts. ${ }^{100}$ However, there do not appear to be detectable increases in expression of granzymes or perforin in kidney allografts undergoing chronic rejection. ${ }^{101,102}$ Nevertheless, because allograft damage resulting from acute rejection episodes contributes to the subsequent development of CAN, early allograft damage through granzyme/perforin-mediated pathways might initiate, in part, the development of CAN in renal allografts. ${ }^{103}$ In addition, fibrotic changes in kidney allografts may be secondary to ischemia resulting from $A V .^{81}$ Expression studies that have failed to identify altered expression of granzymes and perforin in chronic kidney allograft rejection may not have been able to properly evaluate changes specifically in allograft arteries. The potential role of these CTL effector pathways in AV in kidney allografts requires further investigation.

\section{Granzymes and Perforin as Biomarkers of Allograft Rejection}

Increased GrB and perforin mRNA in peripheral blood mononuclear cells from kidney allograft recipients is associated with acute rejection episodes, ${ }^{104-106}$ although an association was not identified in one report. ${ }^{107}$ In addition to the examination of granzyme and perforin expression in isolation, combining their expression analysis with that of other genes in peripheral blood cells may provide additional diagnostic power. For instance, increased expression of the regulatory $T$ cell molecule FoxP3 in peripheral blood cells has been shown to be the most precise marker of acute kidney allograft rejection. ${ }^{106}$ Combining the expression analysis of this gene with that of granzymes and perforin may provide additional increases in the sensitivity and specificity of diagnosis. In addition to peripheral blood cells, analysis of granzyme and perforin gene expression in urine may be a useful method to monitor acute kidney transplant rejection. Detection of perforin mRNA levels above $0.9 \mathrm{fg}$ per $\mu \mathrm{g}$ of total RNA in urine predicts acute rejection with a sensitivity of $83 \%$ and a specificity of $83 \%$, and detection of GrB mRNA levels above $0.4 \mathrm{fg}$ per $\mu \mathrm{g}$ of total RNA predicts acute rejection with a sensitivity of $79 \%$ and a specificity of $77 \% .^{108}$ Therefore, measurement of perforin and/or GrB mRNA levels in urine may also be useful as a non-invasive biomarker of acute kidney allograft rejection.

In attempts to develop biomarkers of acute heart transplant rejection, Schoels et al. ${ }^{109}$ examined mRNA expression of a number of immune-related genes in peripheral blood mononuclear cells of heart transplant recipients and determined that the expression of perforin and $\mathrm{GrB}$, along with six other genes, was significantly increased in patients undergoing acute rejection episodes. Combining increased perforin expression with differential expression of four other immune genes resulted in the ability to predict acute cardiac rejection with a sensitivity of $82 \%$ and a specificity of $84 \%$. Thus, analysis of perforin expression in peripheral blood cells may also be useful in predicting cardiac transplant rejection when combined with expression of other immune regulatory genes. ${ }^{110}$

\section{GrB in Treg Cell Functions}

In addition to its role in effector lymphocyte responses, $\mathrm{GrB}$ is also involved in immune suppression by CD4 + Treg cells. GrB in this T cell subset was found to be required for maximal suppression of CD4 effector T cell responses in vitro, and this was surprisingly independent of perforin. ${ }^{111}$ Further, the suppressive effect of GrB-expressing Treg cells was attributed to contact-mediated killing of effector CD4 T cells. In support of these initial findings, recent studies have shown that $\mathrm{GrB}$ is required for the induction of tolerance in a skin allograft model and in Treg cell inhibition of tumor clearance. ${ }^{112,113}$ With respect to transplantation, tolerance induced by anti-CD154 and donor-specific transfusion is reduced in GrB-deficient mice as well as in mice transgenically overexpressing SPI-6, which is the mouse homolog of the human GrB inhibitor, PI-9. Treg cells that lack functional FoxP3 and GrB fail to induce tolerance, whereas Treg cells that contain a functional gene for either molecule can prolong graft survival to varying degrees. ${ }^{112}$

The effect of tolerance induction on granzyme expression may depend on the type of protocol used. In a rat model of cardiac transplantation, induction of tolerance by donorspecific transfusion prevented acute rejection, but did not diminish the expression of granzymes and perforin within the graft. ${ }^{114}$ On the other hand, analysis of $\mathrm{T}$ cells from patients who have undergone a tolerance-inducing protocol involving bone marrow transplantation and a non-myeloablative preparative regimen showed an increase in the number of FoxP3 T cells and a reduction in GrB-expressing T cells. ${ }^{4}$ Therefore, it will be important to understand the expression of $\mathrm{GrB}$ within regulatory and effector $T$ cell subsets in these patients as well as to reevaluate the usefulness of GrB and FoxP3 as biomarkers of rejection in individuals who have undergone tolerance-inducing protocols.

\section{Conclusions}

Granzymes and perforin are key effectors of cellular immunity. A wide array of studies has established these effector molecules as main mediators of cellular rejection of solid organ allografts. However, the determination that GrB may 
participate in immunosuppressive functions of Treg cells highlights the importance of understanding, in detail, the immunological pathways in which this protease functions to maximize the success of organ transplantation. A more advanced understanding of the pathways that the immune system uses to respond to solid organ allografts may assist in the optimization of immunosuppressive or tolerizing regimens in transplantation management.

\section{Conflict of interest}

The authors declare no conflict of interest.

Acknowledgements. This work was supported in part by an Operating Grant from the Canadian Institutes of Health Research (CIHR), a Grant-in-Aid from the Heart and Stroke Foundation of BC and Yukon, and a New Investigator Award from the CIHR.

1. Taylor DO, Edwards LB, Boucek MM, Trulock EP, Waltz DA, Keck BM et al. Registry of the International Society for Heart and Lung Transplantation: twenty-third official adult heart transplantation report-2006. J Heart Lung Transplant 2006; 25: 869-879.

2. OPTN/SRTR Annual Report 2007, www.ustransplant.org.

3. Srinivas TR, Meier-Kriesche HU. Minimizing immunosuppression, an alternative approach to reducing side effects: objectives and interim result. Clin $J A m$ Soc Nephrol 2008; 3 (Suppl 2): S101-S116.

4. Kawai T, Cosimi AB, Spitzer TR, Tolkoff-Rubin N, Suthanthiran M, Saidman SL et al. HLA-mismatched renal transplantation without maintenance immunosuppression. N Engl J Med 2008; 358: 353-361.

5. Scandling JD, Busque S, Dejbakhsh-Jones S, Benike C, Millan MT, Shizuru JA et al. Tolerance and chimerism after renal and hematopoietic-cell transplantation. N Engl J Med 2008; 358: 362-368.

6. Alexander SI, Smith N, Hu M, Verran D, Shun A, Dorney S et al. Chimerism and tolerance in a recipient of a deceased-donor liver transplant. N Engl J Med 2008; 358: 369-374.

7. Parish IA, Kaech SM. Diversity in CD8(+) T cell differentiation. Curr Opin Immunol 2009; 21: $291-297$

8. Joncker NT, Raulet DH. Regulation of NK cell responsiveness to achieve self-tolerance and maximal responses to diseased target cells. Immunol Rev 2008; 224: 85-97.

9. Raja SM, Metkar SS, Froelich CJ. Cytotoxic granule-mediated apoptosis: unraveling the complex mechanism. Curr Opin Immunol 2003; 15: 528-532.

10. Voskoboinik I, Smyth MJ, Trapani JA. Perforin-mediated target-cell death and immune homeostasis. Nat Rev Immunol 2006; 6: 940-952.

11. Sutton VR, Davis JE, Cancilla M, Johnstone RW, Ruefli AA, Sedelies $K$ et al. Initiation of apoptosis by granzyme $B$ requires direct cleavage of bid, but not direct granzyme B-mediated caspase activation. J Exp Med 2000; 192: 1403-1414.

12. Barry M, Heibein JA, Pinkoski MJ, Lee SF, Moyer RW, Green DR et al. Granzyme B shortcircuits the need for caspase 8 activity during granule-mediated cytotoxic T-lymphocyte killing by directly cleaving Bid. Mol Cell Biol 2000; 20: 3781-3794.

13. Goping IS, Barry M, Liston P, Sawchuk T, Constantinescu G, Michalak KM et al. Granzyme B-induced apoptosis requires both direct caspase activation and relief of caspase inhibition. Immunity 2003; 18: 355-365.

14. Sutton VR, Wowk ME, Cancilla M, Trapani JA. Caspase activation by granzyme $B$ is indirect, and caspase autoprocessing requires the release of proapoptotic mitochondrial factors. Immunity 2003; 18: 319-329.

15. Goping IS, Sawchuk T, Rieger A, Shostak I, Bleackley RC. Cytotoxic T lymphocytes overcome Bcl-2 inhibition: target cells contribute to their own demise. Blood 2008; 111: 2142-2151.

16. Darmon AJ, Nicholson DW, Bleackley RC. Activation of the apoptotic protease CPP32 by cytotoxic T-cell-derived granzyme B. Nature 1995; 377: 446-448.

17. Zhang D, Beresford PJ, Greenberg AH, Lieberman J. Granzymes A and B directly cleave lamins and disrupt the nuclear lamina during granule-mediated cytolysis. Proc Natl Acad Sci USA 2001; 98: 5746-5751.

18. Beresford PJ, Xia Z, Greenberg AH, Lieberman J. Granzyme A loading induces rapid cytolysis and a novel form of DNA damage independently of caspase activation. Immunity 1999; 10: 585-594.

19. Fan Z, Beresford PJ, Oh DY, Zhang D, Lieberman J. Tumor suppressor NM23-H1 is a granzyme A-activated DNase during CTL-mediated apoptosis, and the nucleosome assembly protein SET is its inhibitor. Cell 2003; 112: 659-672.

20. Martinvalet D, Zhu P, Lieberman J. Granzyme A induces caspase-independent mitochondrial damage, a required first step for apoptosis. Immunity 2005; 22 : 355-370.
21. Chowdhury D, Beresford PJ, Zhu P, Zhang D, Sung JS, Demple B et al. The exonuclease TREX1 is in the SET complex and acts in concert with NM23-H1 to degrade DNA during granzyme A-mediated cell death. Mol Cell 2006; 23: 133-142.

22. Martinvalet D, Dykxhoorn DM, Ferrini R, Lieberman J. Granzyme A cleaves a mitochondrial complex I protein to initiate caspase-independent cell death. Cell 2008 133: 681-692.

23. Johnson H, Scorrano L, Korsmeyer SJ, Ley TJ. Cell death induced by granzyme C. Blood 2003; 101: 3093-3101.

24. Hou Q, Zhao T, Zhang H, Lu H, Zhang Q, Sun L et al. Granzyme $H$ induces apoptosis of target tumor cells characterized by DNA fragmentation and Bid-dependent mitochondrial damage. Mol Immunol 2008; 45: 1044-1055.

25. Zhao T, Zhang H, Guo Y, Fan Z. Granzyme $K$ directly processes bid to release cytochrome $\mathrm{c}$ and endonuclease $\mathrm{G}$ leading to mitochondria-dependent cell death. $J$ Biol Chem 2007; 282: 12104-12111.

26. Kagi D, Ledermann B, Burki K, Seiler P, Odermatt B, Olsen KJ et al. Cytotoxicity mediated by $T$ cells and natural killer cells is greatly impaired in perforin-deficient mice. Nature 1994; 369: 31-37.

27. Walsh CM, Matloubian M, Liu CC, Ueda R, Kurahara CG, Christensen JL et al. Immune function in mice lacking the perforin gene. Proc Natl Acad Sci USA 1994; 91: 10854-10858.

28. Lowin B, Beermann F, Schmidt A, Tschopp J. A null mutation in the perforin gene impairs cytolytic T lymphocyte- and natural killer cell-mediated cytotoxicity. Proc Natl Acad Sci USA 1994; 91: 11571-11575.

29. Jordan MB, Hildeman D, Kappler J, Marrack P. An animal model of hemophagocytic lymphohistiocytosis $(\mathrm{HLH})$ : CD8+ T cells and interferon gamma are essential for the disorder. Blood 2004; 104: 735-743.

30. Kagi $D$, Hengartner $H$. Different roles for cytotoxic $T$ cells in the control of infections with cytopathic versus noncytopathic viruses. Curr Opin Immunol 1996; 8: 472-477.

31. Ebnet K, Hausmann M, Lehmann-Grube F, Mullbacher A, Kopf M, Lamers $M$ et al. Granzyme A-deficient mice retain potent cell-mediated cytotoxicity. EMBO J 1995; 14: 4230-4239.

32. Zajac AJ, Dye JM, Quinn DG. Control of lymphocytic choriomeningitis virus infection in granzyme B deficient mice. Virology 2003; 305: 1-9.

33. Mullbacher A, Waring P, Tha Hla R, Tran T, Chin S, Stehle T et al. Granzymes are the essential downstream effector molecules for the control of primary virus infections by cytolytic leukocytes. Proc Natl Acad Sci USA 1999; 96: 13950-13955.

34. Heusel JW, Wesselschmidt RL, Shresta S, Russell JH, Ley TJ. Cytotoxic lymphocytes require granzyme $\mathrm{B}$ for the rapid induction of DNA fragmentation and apoptosis in allogeneic target cells. Cell 1994; 76: 977-987.

35. Metkar SS, Menaa C, Pardo J, Wang B, Wallich R, Freudenberg M et al. Human and mouse granzyme A induce a proinflammatory cytokine response. Immunity 2008; 29: 720-733.

36. Hanson CA, Bolling SF, Stoolman LM, Schlegelmilch JA, Abrams GD, Miska PT et al. Cytoimmunologic monitoring and heart transplantation. J Heart Transplant 1988; 7: 424-429.

37. Trentin L, Zambello R, Faggian G, Livi U, Thiene G, Gasparotto G et al. Phenotypic and functional characterization of cytotoxic cells derived from endomyocardial biopsies in human cardiac allografts. Cell Immunol 1992; 141: 332-341.

38. Schenk AD, Nozaki T, Rabant M, Valujskikh A, Fairchild RL. Donor-reactive CD8 memory T cells infiltrate cardiac allografts within 24-h posttransplant in naive recipients. Am J Transplant 2008; 8: 1652-1661.

39. Chan SY, DeBruyne LA, Goodman RE, Eichwald EJ, Bishop DK. In vivo depletion of CD8+ T cells results in Th2 cytokine production and alternate mechanisms of allograft rejection. Transplantation 1995; 59: 1155-1161.

40. Youssef AR, Otley C, Mathieson PW, Smith RM. Role of CD4+ and CD8+ T cells in murine skin and heart allograft rejection across different antigenic desparities. Transpl Immunol 2004; 13: 297-304.

41. Maier S, Tertilt C, Chambron N, Gerauer K, Huser N, Heidecke CD et al. Inhibition of natural killer cells results in acceptance of cardiac allografts in CD28-/- mice. Nat Med 2001; 7: 557-562.

42. Kondo T, Morita K, Watarai Y, Auerbach MB, Taub DD, Novick AC et al. Early increased chemokine expression and production in murine allogeneic skin grafts is mediated by natural killer cells. Transplantation 2000; 69: 969-977.

43. Ljunggren HG, Karre K. In search of the 'missing self': MHC molecules and NK cell recognition. Immunol Today 1990; 11: 237-244

44. Hameed A, Truong LD, Price V, Kruhenbuhl O, Tschopp J. Immunohistochemical localization of granzyme B antigen in cytotoxic cells in human tissues. Am J Pathol 1991; 138: 1069-1075.

45. Griffiths GM, Namikawa R, Mueller C, Liu CC, Young JD, Billingham M et al. Granzyme A and perforin as markers for rejection in cardiac transplantation. Eur J Immunol 1991; 21: 687-693.

46. Clement MV, Haddad P, Soulie A, Benvenuti C, Lichtenheld MG, Podack ER et al. Perforin and granzyme $B$ as markers for acute rejection in heart transplantation. Int Immunol 1991; 3: 1175-1181.

47. Lipman ML, Stevens AC, Strom TB. Heightened intragraft CTL gene expression in acutely rejecting renal allografts. J Immunol 1994; 152: 5120-5127.

48. Kummer JA, Wever PC, Kamp AM, ten Berge IJ, Hack CE, Weening JJ. Expression of granzyme $A$ and $B$ proteins by cytotoxic lymphocytes involved in acute renal allograft rejection. Kidney Int 1995; 47: 70-77. 
49. Krams SM, Villanueva JC, Quinn MB, Martinez OM. Expression of the cytotoxic T-cell mediator granzyme B during liver allograft rejection. Transpl Immunol 1995; 3: 162-166.

50. Legros-Maida S, Soulie A, Benvenuti C, Wargnier A, Vallee N, Berthou C et al. Granzyme $B$ and perforin can be used as predictive markers of acute rejection in heart transplantation. Eur J Immunol 1994; 24: 229-233.

51. Rowshani AT, Florquin S, Bemelman F, Kummer JA, Hack CE, Ten Berge IJ. Hyperexpression of the granzyme B inhibitor PI-9 in human renal allografts: a potential mechanism for stable renal function in patients with subclinical rejection. Kidney Int 2004 66: 1417-1422.

52. Felzen B, Berke G, Rosen D, Coleman R, Tschopp J, Young JD et al. Effects of purified perforin and granzyme $A$ from cytotoxic $T$ lymphocytes on guinea pig ventricular myocytes. Cardiovasc Res 1994; 28: 643-649.

53. Alpert S, Lewis NP, Ross H, Fowler M, Valantine HA. The relationship of granzyme A and perforin expression to cardiac allograft rejection and dysfunction. Transplantation 1995 60: $1478-1485$.

54. Miltenburg AM, Meijer-Paape ME, Daha MR, van Bockel JH, Weening JJ, van Es LA et al. Donor-specific lysis of human kidney proximal tubular epithelial cells by renal allograftinfiltrating lymphocytes. Transplantation 1989; 48: 296-302.

55. Wever PC, Boonstra JG, Laterveer JC, Hack CE, van der Woude FJ, Daha MR et al. Mechanisms of lymphocyte-mediated cytotoxicity in acute renal allograft rejection. Transplantation 1998; 66: 259-264

56. Getachew $Y$, Stout-Delgado H, Miller BC, Thiele DL. Granzyme C supports efficient CTLmediated killing late in primary alloimmune responses. J Immunol 2008; 181: 7810-7817.

57. Bailey NC, Kelly CJ. Nephritogenic T cells use granzyme $\mathrm{C}$ as a cytotoxic mediator. Eur J Immunol 1997: 27: 2302-2309.

58. Choy JC, Wang Y, Tellides G, Pober JS. Induction of inducible NO synthase in bystander human T cells increases allogeneic responses in the vasculature. Proc Natl Acad Sci USA 2007; 104: 1313-1318.

59. Jutte $\mathrm{NH}$, Heijse $\mathrm{P}$, van Batenburg MH, Vaessen LM, Mochtar B, Balk AH et al. Donor heart endothelial cells as targets for graft infiltrating lymphocytes after clinical cardiac transplantation. Transpl Immunol 1993; 1: 39-44.

60. Choy JC, Cruz RP, Kerjner A, Geisbrecht J, Sawchuk T, Fraser SA et al. Granzyme B induces endothelial cell apoptosis and contributes to the development of transplant vascular disease. Am J Transplant 2005; 5: 494-499.

61. Buzza MS, Zamurs L, Sun J, Bird CH, Smith Al, Trapani JA et al. Extracellular matrix remodeling by human granzyme $B$ via cleavage of vitronectin, fibronectin, and laminin J Biol Chem 2005; 280: 23549-23558.

62. Zheng L, Ben LH, Pober JS, Bothwell AL. Porcine endothelial cells, unlike human endothelial cells, can be killed by human CTL via Fas ligand and cannot be protected by Bcl-2. J Immunol 2002; 169: 6850-6855

63. Kreisel D, Krasinskas AM, Krupnick AS, Gelman AE, Balsara KR, Popma SH et al. Vascular endothelium does not activate $\mathrm{CD} 4+$ direct allorecognition in graft rejection. J Immunol 2004; 173: 3027-3034.

64. Imanishi T, McBride J, Ho Q, O'Brien KD, Schwartz SM, Han DK. Expression of cellular FLICE-inhibitory protein in human coronary arteries and in a rat vascular injury model. $A m$ $J$ Pathol 2000; 156: 125-137.

65. Bannerman DD, Tupper JC, Ricketts WA, Bennett CF, Winn RK, Harlan JM. A constitutive cytoprotective pathway protects endothelial cells from lipopolysaccharide-induced apoptosis. J Biol Chem 2001; 276: 14924-14932.

66. Zheng L, Gibson TF, Schechner JS, Pober JS, Bothwell AL. Bcl-2 transduction protects human endothelial cell synthetic microvessel grafts from allogeneic $T$ cells in vivo. $J$ Immunol 2004; 173: 3020-3026.

67. Sis B, Famulski KS, Allanach KL, Zhu LF, Halloran PF. IFN-gamma prevents early perforin-granzyme-mediated destruction of kidney allografts by inducing donor class products in the kidney. Am J Transplant 2007; 7: 2301-2310.

68. Schulz M, Schuurman HJ, Joergensen J, Steiner C, Meerloo T, Kagi D et al. Acute rejection of vascular heart allografts by perforin-deficient mice. Eur J Immunol 1995; 25 474-480.

69. Halloran PF, Urmson J, Ramassar V, Melk A, Zhu LF, Halloran BP et al. Lesions of T-cellmediated kidney allograft rejection in mice do not require perforin or granzymes $\mathrm{A}$ and $\mathrm{B}$. Am J Transplant 2004; 4: 705-712.

70. Wasowska BA, Qian Z, Behrens E, Cangello D, Sanfilippo F, Baldwin 3rd WM. Inhibition of acute cardiac allograft rejection in immunoglobulin-deficient mice. Transplant Proc 1999; 31: 136

71. Wasowska BA, Qian Z, Cangello DL, Behrens E, Van Tran K, Layton J et al. Passive transfer of alloantibodies restores acute cardiac rejection in IgKO mice. Transplantation 2001; 71: 727-736.

72. Singh N, Pirsch J, Samaniego M. Antibody-mediated rejection: treatment alternatives and outcomes. Transplant Rev (Orlando) 2009; 23: 34-46.

73. Uber WE, Self SE, Van Bakel AB, Pereira NL. Acute antibody-mediated rejection following heart transplantation. Am J Transplant 2007; 7: 2064-2074.

74. Bretscher PA, Havele C. Cyclosporin A can switch the immune response induced by antigen from a humoral to a cell-mediated mode. Eur J Immunol 1992; 22: 349-355.

75. Vessie EL, Hirsch GM, Lee TD. Aortic allograft vasculopathy is mediated by CD8(+) T cells in Cyclosporin A immunosuppressed mice. Transpl Immunol 2005; 15: 35-44.

76. Le Moine A, Goldman M. Non-classical pathways of cell-mediated allograft rejection: new challenges for tolerance induction? Am J Transplant 2003; 3: 101-106.
77. Miller $C$, DeWitt CW. Cellular and humoral responses to major and minor histocompatibility antigens. Transplant Proc 1973; 5: 303-305.

78. Choy JC, Kerjner A, Wong BW, McManus BM, Granville DJ. Perforin mediates endothelial cell death and resultant transplant vascular disease in cardiac allografts. Am J Pathol 2004; 165: 127-133.

79. Fanslow WC, Sims JE, Sassenfeld H, Morrissey PJ, Gillis S, Dower SK et al. Regulation of alloreactivity in vivo by a soluble form of the interleukin-1 receptor. Science 1990; 248: 739-742.

80. Shiraishi M, Csete M, Yasunaga C, McDiarmid SV, Vannice JL, Busuttil RW et al. The inhibitor cytokine interleukin-1 receptor antagonist synergistically augments cyclosporine immunosuppression in a rat cardiac allograft model. J Surg Res 1995; 58: $465-470$.

81. Libby P, Pober JS. Chronic rejection. Immunity 2001; 14: 387-397.

82. Mitchell RN, Libby P. Vascular remodeling in transplant vasculopathy. Circ Res 2007; 100: 967-978.

83. Salomon RN, Hughes CC, Schoen FJ, Payne DD, Pober JS, Libby P. Human coronary transplantation-associated arteriosclerosis. Evidence for a chronic immune reaction to activated graft endothelial cells. Am J Pathol 1991; 138: 791-798.

84. Cramer DV, Wu GD, Chapman FA, Cajulis E, Wang HK, Makowka L. Lymphocytic subsets and histopathologic changes associated with the development of heart transplant arteriosclerosis. J Heart Lung Transplant 1992; 11 (3 Pt 1): 458-466.

85. Shi C, Lee WS, He Q, Zhang D, Fletcher Jr DL, Newell JB et al. Immunologic basis of transplant-associated arteriosclerosis. Proc Natl Acad Sci USA 1996; 93: 4051-4056.

86. Tellides G, Pober JS. Interferon-gamma axis in graft arteriosclerosis. Circ Res 2007; 100: 622-632.

87. Choy JC, Podor TJ, Yanagawa B, Lai JC, Granville DJ, Walker DC et al. The regulation and consequences of immune-mediated cell death in atheromatous diseases. Cardiovasc Toxicol 2003; 3: 269-282.

88. Ross R, Glomset J, Harker L. Response to injury and atherogenesis. Am J Pathol 1977; 86: 675-684.

89. Dong C, Redenbach D, Wood S, Battistini B, Wilson JE, McManus BM. The pathogenesis of cardiac allograft vasculopathy. Curr Opin Cardiol 1996; 11: 183-190.

90. Dong C, Wilson JE, Winters GL, McManus BM. Human transplant coronary artery disease: pathological evidence for Fas-mediated apoptotic cytotoxicity in allograft arteriopathy. Lab Invest 1996; 74: 921-931.

91. Lai JC, Tranfield EM, Walker DC, Dyck J, Keriner A, Loo S et al. Ultrastructural evidence of early endothelial damage in coronary arteries of rat cardiac allografts. J Heart Lung Transplant 2003; 22: 993-1004.

92. Hameed A, Olsen KJ, Cheng L, Fox 3rd WM, Hruban RH, Podack ER Immunohistochemical identification of cytotoxic lymphocytes using human perforin monoclonal antibody. Am J Pathol 1992; 140: 1025-1030.

93. Fox 3rd WM, Hameed A, Hutchins GM, Reitz BA, Baumgartner WA, Beschorner WE et al. Perforin expression localizing cytotoxic lymphocytes in the intimas of coronary arteries with transplant-related accelerated arteriosclerosis. Hum Pathol 1993; 24: 477-482.

94. Choy JC, McDonald PC, Suarez AC, Hung VH, Wilson JE, McManus BM et al. Granzyme $B$ in atherosclerosis and transplant vascular disease: association with cell death and atherosclerotic disease severity. Mod Pathol 2003; 16: 460-470.

95. Reidy MA, Fingerle J, Lindner V. Factors controlling the development of arterial lesions after injury. Circulation 1992; 86 (6 Suppl): |||43-II|46.

96. Clarke MC, Figg N, Maguire JJ, Davenport AP, Goddard M, Littlewood TD et al. Apoptosis of vascular smooth muscle cells induces features of plaque vulnerability in atherosclerosis. Nat Med 2006; 12: 1075-1080.

97. Skaro Al, Liwski RS, Zhou J, Vessie EL, Lee TD, Hirsch GM. CD8+ T cells mediate aortic allograft vasculopathy by direct killing and an interferon-gamma-dependent indirect pathway. Cardiovasc Res 2005; 65: 283-291.

98. Choy JC, Hung VH, Hunter AL, Cheung PK, Motyka B, Goping IS et al. Granzyme B induces smooth muscle cell apoptosis in the absence of perforin: involvement of extracellular matrix degradation. Arterioscler Thromb Vasc Biol 2004; 24: 2245-2250.

99. Mannon RB, Griffiths R, Ruiz P, Platt JL, Coffman TM. Absence of donor MHC antigen expression ameliorates chronic kidney allograft rejection. Kidney Int 2002; 62: 290-300.

100. Robertson H, Ali S, McDonnell BJ, Burt AD, Kirby JA. Chronic renal allograft dysfunction: the role of $T$ cell-mediated tubular epithelial to mesenchymal cell transition. J Am Soc Nephrol 2004; 15: 390-397.

101. Sharma VK, Bologa RM, Li B, Xu GP, Lagman M, Hiscock W et al. Molecular executors of cell death-differential intrarenal expression of Fas ligand, Fas, granzyme B, and perforin during acute and/or chronic rejection of human renal allografts. Transplantation 1996; 62 : 1860-1866.

102. Nocera A, Tagliamacco A, Ferrante A, Fontana I, Rolla D, De Palma R et al. Cytotoxic molecule mRNA expression in chronically rejected human kidney allografts. Transplant Proc 2005; 37: 2476-2478.

103. Almond PS, Matas A, Gillingham K, Dunn DL, Payne WD, Gores P et al. Risk factors for chronic rejection in renal allograft recipients. Transplantation 1993; 55: 752-756; discussion 756-7.

104. Vasconcellos LM, Schachter AD, Zheng XX, Vasconcellos LH, Shapiro M, Harmon WE et al. Cytotoxic lymphocyte gene expression in peripheral blood leukocytes correlates with rejecting renal allografts. Transplantation 1998; 66: 562-566. 
105. Simon T, Opelz G, Wiesel M, Ott RC, Susal C. Serial peripheral blood perforin and granzyme $B$ gene expression measurements for prediction of acute rejection in kidney graft recipients. Am J Transplant 2003; 3: 1121-1127.

106. Aquino-Dias EC, Joelsons G, da Silva DM, Berdichevski RH, Ribeiro AR, Veronese FJ et al. Non-invasive diagnosis of acute rejection in kidney transplants with delayed graft function. Kidney Int 2008; 73: 877-884.

107. Alakulppi NS, Kyllonen LE, Partanen J, Salmela KT, Laine JT. Diagnosis of acute renal allograft rejection by analyzing whole blood mRNA expression of lymphocyte marker molecules. Transplantation 2007; 83: 791-798.

108. Li B, Hartono C, Ding R, Sharma VK, Ramaswamy R, Qian B et al. Noninvasive diagnosis of renal-allograft rejection by measurement of messenger RNA for perforin and granzyme B in urine. N Engl J Med 2001; 344: 947-954.

109. Schoels M, Dengler TJ, Richter R, Meuer SC, Giese T. Detection of cardiac allograft rejection by real-time PCR analysis of circulating mononuclear cells. Clin Transplant 2004; 18: 513-517.
110. Hidalgo LG, Einecke G, Allanach K, Mengel M, Sis B, Mueller TF et al. The transcriptome of human cytotoxic $T$ cells: measuring the burden of $C T L$-associated transcripts in human kidney transplants. Am J Transplant 2008; 8: 637-646.

111. Gondek DC, Lu LF, Quezada SA, Sakaguchi S, Noelle RJ. Cutting edge: contactmediated suppression by $\mathrm{CD} 4+\mathrm{CD} 25+$ regulatory cells involves a granzyme B-dependent, perforin-independent mechanism. J Immunol 2005; 174: 1783-1786.

112. Gondek DC, Devries V, Nowak EC, Lu LF, Bennett KA, Scott ZA et al. Transplantation survival is maintained by granzyme $B+$ regulatory cells and adaptive regulatory $T$ cells. $\mathrm{J}$ Immunol 2008; 181: 4752-4760.

113. Cao X, Cai SF, Fehniger TA, Song J, Collins LI, Piwnica-Worms DR et al. Granzyme B and perforin are important for regulatory $T$ cell-mediated suppression of tumor clearance. Immunity 2007; 27: 635-646.

114. Bugeon L, Cuturi MC, Paineau J, Anegon I, Soulillou JP. Similar levels of granzyme A and perforin $\mathrm{mRNA}$ expression in rejected and tolerated heart allografts in donor-specific tolerance in rats. Transplantation 1993; 56: 405-408. 